\title{
Multi-enzyme complexes in thermophilic organisms: isolation and characterization of the pyruvate dehydrogenase complex from Thermus aquaticus AT62
}

\author{
Edith MaAs, Harry Pospichal, $†$ Reinhard Köplin $\ddagger$ and Hans Bisswanger* \\ Physiologisch-chemisches Institut der Universität Tübingen, Hoppe-Seyler-Str. 4, D-7400 Tübingen, Germany
}

(Received 22 July 1991; revised 11 November 1991; accepted 4 December 1991)

\begin{abstract}
The pyruvate dehydrogenase complex from the thermophilic bacterium Thermus aquaticus was purified by Triton X-100 extraction and chromatography on phenyl-Sepharose CL-4B and HPLC-hydroxyapatite. The electrophoretic pattern of the purified enzyme complex was similar to that of the enzyme complex from Bacillus subtilis, with four bands: the $\alpha$-chain $\left(M_{\mathrm{r}} 39600\right)$ and $\beta$-chain $\left(M_{\mathrm{r}} 37500\right)$ of the pyruvate dehydrogenase component, the dihydrolipoamide acetyltransferase component $\left(M_{\mathrm{r}} 58500\right)$ and the dihydrolipoamide dehydrogenase component $\left(M_{\mathrm{r}}\right.$ 53900). Antibodies against the purified $T$. aquaticus pyruvate dehydrogenase complex cross-reacted with the enzyme complex from $B$. subtilis and, to a minor extent, with that from bovine heart. No cross-reactivity could be observed with the enzyme complex from Escherichia coli. The $T$. aquaticus enzyme complex had a temperature maximum at $72{ }^{\circ} \mathrm{C}$. 2-Oxobutyrate was a poor substrate and other 2-oxoacids were competitive inhibitors of the overall reaction. Long-chain 2-oxoacids showed a greater inhibitory effect, possibly caused by hydrophobic interactions. GTP inhibited the enzyme activity. Regulation of the pyruvate dehydrogenase complex from $T$. aquaticus by allosteric mechanisms or by reversible phosphorylation could not be demonstrated.
\end{abstract}

\section{Introduction}

Although thermostable enzymes from thermophilic organisms have been thoroughly investigated (Argos et al., 1979; Jaenicke, 1981; Zuber, 1981), little is known about the special features of multi-enzyme complexes from such organisms. Henderson et al. (1979) showed that the pyruvate dehydrogenase complex from Bacillus stearothermophilus appeared to be similar in structure to that from mesophilic organisms (Packman et al., 1988).

Pyruvate dehydrogenase complexes can be subdivided into two classes. In the type I pyruvate dehydrogenase complex from Gram-negative bacteria, the 24 identical subunits of dihydrolipoamide acetyltransferase (E2, EC 2.3.1.12) form a cubic core. The 24 identical subunits of the pyruvate dehydrogenase component (E1, EC 1.2.4.1) bind to the edges of this cube in an octahedral symmetry, while 12 subunits of the dihydro-

\footnotetext{
* Author for correspondence. Tel. 7071 294183; fax 7071293361.

† Present address: Swiss Tropical Institute, Socinstrasse 57, CH-4051 Basel, Switzerland.

$\ddagger$ Present address: Biologie VI, Universität Bielefeld, D-4800 Bielefeld, Germany.
}

lipoamide dehydrogenase component (E3, EC 1.8.1.4) are attached to its faces. The type II pyruvate dehydrogenase complex, which is found in Gram-positive bacteria and in eukaryotes, possesses a similar structure with an E2 core surrounded by subunits of the E1 and E3 components. There are, however, 60 subunits of both the $\mathrm{E} 1$ and the E2 components, so that the complex has an icosahedral symmetry. The subunits of the E1 component are formed from two non-identical polypeptide chains $(\alpha$ and $\beta$ ). Component $X$, whose function is still unknown, is found in eukaryotes. In higher organisms regulatory enzymes, catalysing reversible phosphorylation of the El component, are also bound to the enzyme complex (Reed, 1974, 1981; Wieland, 1983; Yeaman, 1989).

Here we report the isolation and characterization of a type II pyruvate dehydrogenase complex from the thermophilic bacterium Thermus aquaticus.

\section{Methods}

Growth of bacteria. Thermus aquaticus AT-62 (DSM 674) was obtained from the Deutsche Sammlung für Mikroorganismen, Braunschweig, Germany. Three different media were used for cell 
cultivation. A medium containing $0.8 \%$ proteose peptone, $0.4 \%$ yeast extract, and $0.3 \% \mathrm{NaCl}$ in distilled water (Oshima \& Imahori, 1974), and a minimal medium (Yoshida et al., 1984) supplemented with $0.2 \%$ sodium pyruvate were used for $250 \mathrm{ml}$ cultures grown in gently shaken flasks at $70^{\circ} \mathrm{C}$ for $15 \mathrm{~h}$. A semi-synthetic medium, M162 (Degryse et al., 1978), supplemented with $0.2 \%$ sodium pyruvate, was used in a 20 litre Intensor 20b fermenter (Giovanola Frères, Monthy, Switzerland); cultures were grown for $15 \mathrm{~h}$ at $70^{\circ} \mathrm{C}$ with 0.2 vols vol. ${ }^{-1} \mathrm{~min}^{-1}$ air and stirring (1200 r.p.m.).

Crude extracts were obtained by sonication of a suspension of the centrifuged cells in 2 vols 50 mM-potassium phosphate, $\mathrm{pH} 7 \cdot 5,0.1 \mathrm{mM}$ EDTA, 1 mM-PMSF, 2 mM-DTT, $3 \mathrm{~mm}-\mathrm{MgCl}_{2}$ and $5 \mathrm{~mm}-\beta$-mercaptoethanol, for $4 \mathrm{~min}$ at $50 \mathrm{~W}$ at $4{ }^{\circ} \mathrm{C}$, using a type $\mathrm{B}-12$ sonicator (Branson). Cell debris was removed by centrifugation at $38000 \mathrm{~g}$ for $30 \mathrm{~min}$.

Enzyme assays and protein determination. The overall activity of the pyruvate dehydrogenase complex was measured according to Schwartz \& Reed (1970), and the activity of the E3 component according to Schmincke-Ott \& Bisswanger (1981). The reduction of NAD was in both cases followed photometrically at $340 \mathrm{~nm}$ at $70^{\circ} \mathrm{C}$ for the $T$. aquaticus enzymes and at $30^{\circ} \mathrm{C}$ for the enzymes from other sources. The enzyme activities were given in nkat (nmol NADH produced $\mathbf{s}^{-1}$ ).

Protein concentration. Protein concentration was determined according to a modified Lowry method (Hartree, 1972). The BCA protein assay reagent (Pierce) was used for purified enzyme samples.

Purification of the pyruvate dehydrogenase complex. Triton X-100 extraction. The crude extract was warmed to room temperature and Triton X-100 was added to a final concentration of $20 \%(\mathrm{v} / \mathrm{v})$. The mixture was stirred for $10 \mathrm{~min}$, then centrifuged at $100000 \mathrm{~g}$ at room temperature for $30 \mathrm{~min}$. The clear yellow lower layer containing the enzyme activity was carefully removed by a syringe through the upper layer which contained the Triton $X-100$.

Hydrophobic chromatography. A $2 \times 16 \mathrm{~cm}$ phenyl-Sepharose CL-4B column was equilibrated with $1 \mathrm{M}$-potassium phosphate, $\mathrm{pH} 7.0$, $0.1 \mathrm{~mm}$-DTT, $0.1 \mathrm{~mm}$-EDTA. DTT, EDTA and $2 \mathrm{M}$-potassium phosphate, $\mathrm{pH} 7.0$ were added to the Triton $\mathrm{X}-100$ extract to give a final concentration of $1 \mathrm{M}$-potassium phosphate, pH 7.0, 0.1 mM-DTT, $0.1 \mathrm{~mm}$-EDTA. The column was run with a flow rate of $2 \mathrm{ml} \mathrm{min}^{-1}$ with an FPLC pump system (Pharmacia-LKB). A $150 \mathrm{ml}$ gradient of 1 to $0.01 \mathrm{M}$-potassium phosphate, pH 7.0, 0.1 mM-DTT, 0.1 mM-EDTA was applied and $5 \mathrm{ml}$ fractions were collected. Active fractions were pooled and layered carefully onto the same volume of $35 \%(w / v)$ sucrose

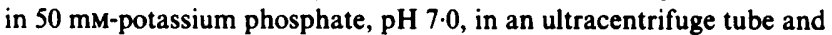
centrifuged for $4 \mathrm{~h}$ at $176000 \mathrm{~g}$ and $4^{\circ} \mathrm{C}$. The clear yellow pellet was dissolved in a small volume of $25 \mathrm{~mm}$-potassium phosphate, $\mathrm{pH} 7 \cdot 0$.

Adsorption chromatography. The enzyme was applied to a $7.8 \times 100 \mathrm{~mm}$ Bio-Gel HPHT hydroxyapatite column, equilibrated with $25 \mathrm{~mm}$-potassium phosphate, pH 7.0, 0.2 mM-DTT, and eluted at a flow rate of $0.1 \mathrm{ml} \mathrm{min}^{-1}$. For each run $1 \mathrm{mg}$ protein was applied to the column in $1 \mathrm{ml}$, and the process was repeated in order to purify more protein. Elution was with a $10 \mathrm{ml}$ linear gradient of 25 to $500 \mathrm{mM}$ potassium phosphate $\mathrm{pH} 7.0,0.2 \mathrm{~mm}$-DTT, and $0.2 \mathrm{ml}$ fractions were collected.

Electrophoresis. SDS-PAGE (Laemmli, 1970) was used with a gradient of 10 to $20 \%(w / v)$ acrylamide. Staining of protein bands was with Coomassie brilliant blue R-250 (Fairbanks et al., 1971).

Sucrose gradient centrifugation. The enzyme preparation $(50 \mu \mathrm{l})$ was layered on to a linear $5.2 \mathrm{ml}$ gradient from 10 to $50 \%(\mathrm{w} / \mathrm{v})$ sucrose in $0.05 \mathrm{M}-\mathrm{MOPS} / \mathrm{HCl}, \mathrm{pH} 7.0$, and centrifuged in a SW $65 \mathrm{Ti}$ swinging bucket rotor (Beckman) at $145000 \mathrm{~g}$ and $4^{\circ} \mathrm{C}$ for $3 \mathrm{~h}$ (Martin \& Ames, 1961).
Electron microscopy. The samples were negatively stained with uranyl oxalate according to Mellema et al. (1967) on copper grids (mesh 400, Veco, Solingen, Germany), and examined with an EM109 electron microscope (Zeiss).

Isolation of rabbit antibodies. The antigen $(0.8 \mathrm{mg}$ protein in $1 \mathrm{ml}$ $50 \mathrm{~mm}-\mathrm{MOPS} / \mathrm{HCl}, \mathrm{pH} \mathrm{7.0,} \mathrm{emulsified} \mathrm{in} 1 \mathrm{ml}$ of complete Freund's adjuvant by sonication for some seconds) was injected subcutaneously into a rabbit. After 2 and 3 weeks, two further injections were given of $0.2 \mathrm{mg}$ antigen in $0.5 \mathrm{ml} \mathrm{MOPS} / \mathrm{HCl}, \mathrm{pH} 7.0$, emulsified in $0.5 \mathrm{ml}$ incomplete Freund's adjuvant. Blood (ca. $10 \mathrm{ml}$ ) was taken $28 \mathrm{~d}$ after the first injection. The immunoglobulin fraction was prepared from serum by affinity chromatography on a $1 \times 5 \mathrm{~cm}$ Protein A-Sepharose CL-4B column, equilibrated with 0.1 M-potassium phosphate, $\mathrm{pH}$ 8.0.

Labelling with ${ }^{32} P$. Cells of $T$. aquaticus, grown in $250 \mathrm{ml}$ of medium M162, supplemented with $92.5 \mathrm{MBq}{ }^{32} \mathrm{P}_{i}$, at $70^{\circ} \mathrm{C}$ for $8 \mathrm{~h}$, were collected by centrifugation at $10000 \mathrm{~g}$ for $10 \mathrm{~min}$. After sonication the crude extract was centrifuged at $38000 \mathrm{~g}$ for $30 \mathrm{~min}$. Samples containing $0.1 \mu \mathrm{g}$ protein each were applied to a 10 to $15 \%(\mathrm{w} / \mathrm{v})$ gradient acrylamide gel and run in a PhastSystem electrophoresis apparatus (Pharmacia-LKB). After silver staining according to Heukeshoven \& Dernick (1985) the gel was dried for $2 \mathrm{~h}$ at $70^{\circ} \mathrm{C}$. Kodak X-OMAT TM AR film was exposed to the gel for $15 \mathrm{~d}$ with a Kodak X-Omatic regular intensifying screen at room temperature.

Chemicals. Proteose peptone no. 3, yeast extract and complete and incomplete Freund's adjuvant were purchased from Difco; sodium pyruvate and other media and buffers were from Merck; 1,4-dithiothreitol (DTT), phenylmethylsulphonyl fluoride (PMSF), and substrates and cofactors for the enzyme tests were from Boehringer Mannheim; acrylamide, Coomassie brilliant blue R-250, glyoxylic acid, $N, N^{\prime}$-methylene-bis-acrylamide, MOPS, SDS and Triton X-100 were from Serva; 2-oxobutyrate, 2-oxo-n-valerate and 2-oxo-n-caprylate were from Fluka and sodium 2-oxocaproate was from Sigma. Phenyl-Sepharose CL-4B and Protein A-Sepharose CL-4B were obtained from Pharmacia-LKB; the Bio-Gel HPHT column was from Bio-Rad; ${ }^{32} \mathbf{P}_{\mathrm{i}}$ was from Amersham.

\section{Results}

\section{Induction of the pyruvate dehydrogenase activity in T. aquaticus}

To test whether in $T$. aquaticus biosynthesis of the pyruvate dehydrogenase complex is induced by pyruvate this organism was grown on the three different media all supplemented either with $0.2 \%$ sodium pyruvate or glucose. The largest cell yields and highest enzyme activities were obtained with the semi-synthetic medium (Table 1). Pyruvate induced the enzyme activity in all three media, but most efficiently in M162 medium (Table 1). The dependence of the enzyme activity on the concentration of pyruvate or glucose in M162 medium was tested. The activity increased to a plateau above $0.4 \%$ for pyruvate, which was double that for glucose.

\section{Purification and molecular mass determination of the pyruvate dehydrogenase complex from $T$. aquaticus}

The purification of pyruvate dehydrogenase from $T$. aquaticus was difficult because of the great instability of 
Table 1. Cell yields and pyruvate dehydrogenase activities after cultivation of $T$. aquaticus AT62 on different media, supplemented with various carbon sources

The bacteria were grown in $500 \mathrm{ml}$ of culture medium at $70^{\circ} \mathrm{C}$. After $15 \mathrm{~h}$ the cells were collected by centrifugation. The overall activity of the pyruvate dehydrogenase complex was measured in the crude extract.

\begin{tabular}{clcc}
\hline \hline $\begin{array}{c}\text { Culture } \\
\text { medium }\end{array}$ & $\begin{array}{c}\text { Carbon source } \\
(0.2 \%)\end{array}$ & $\begin{array}{c}\text { Cell yield } \\
(\mathrm{g})\end{array}$ & $\begin{array}{c}\text { Enzyme activity } \\
\text { [nkat (mg protein) }\end{array}$ \\
\hline Complete & Pyruvate & 0.5 & 0.70 \\
medium & Glucose & 0.6 & 0.52 \\
Semi-synthetic & Pyruvate & 1.8 & 3.9 \\
medium M162 & Glucose & 2.0 & 2.34 \\
& Glutamate & 1.0 & 0.47 \\
& Glycerol & 0.8 & 0.23 \\
& Acetate & 1.1 & 0.48 \\
Minimal salt & Succinate & 1.2 & 0.20 \\
medium & Pyruvate & 0.96 & 1.42 \\
\hline \hline
\end{tabular}

Table 2. Purification of the pyruvate dehydrogenase complex from $T$. aquaticus

\begin{tabular}{|c|c|c|c|c|c|c|}
\hline \multirow[b]{2}{*}{$\begin{array}{l}\text { Purification } \\
\text { step }\end{array}$} & \multirow[b]{2}{*}{$\begin{array}{l}\text { Vol. } \\
(\mathrm{ml})\end{array}$} & \multirow[b]{2}{*}{$\begin{array}{l}\text { Protein } \\
\text { (mg) }\end{array}$} & \multicolumn{2}{|c|}{ Enzyme activity } & \multirow[b]{2}{*}{$\begin{array}{l}\text { Yield } \\
(\%)\end{array}$} & \multirow[b]{2}{*}{$\begin{array}{l}\text { Purification } \\
\text { factor }\end{array}$} \\
\hline & & & $\begin{array}{l}\text { Total } \\
\text { (nkat) }\end{array}$ & $\begin{array}{c}\text { Specific } \\
{[\text { [nkat (mg }} \\
\left.\text { protein })^{-1}\right]\end{array}$ & & \\
\hline Crude extract & 28 & 420 & $78 \cdot 3$ & $0 \cdot 196$ & $-*$ & $-\bullet$ \\
\hline $\begin{array}{l}\text { Triton X-100 } \\
\text { extraction }\end{array}$ & 24 & 276 & $88 \cdot 1$ & 0.319 & 100 & 1 \\
\hline $\begin{array}{l}\text { Phenyl-Sepharose } \\
\text { CL-4B chroma- } \\
\text { tography }\end{array}$ & 30 & $121 \cdot 5$ & $80 \cdot 6$ & 0.663 & $91 \cdot 5$ & $2 \cdot 08$ \\
\hline Ultracentrifugation & 1 & $2 \cdot 1$ & $36 \cdot 8$ & 17.52 & $41 \cdot 8$ & $54 \cdot 9$ \\
\hline $\begin{array}{l}\text { Hydroxyapatite } \\
\text { chromatography }\end{array}$ & 1.6 & $0 \cdot 34$ & $31 \cdot 3$ & 93.02 & $35 \cdot 3$ & $291 \cdot 6$ \\
\hline
\end{tabular}

* Because of perturbations in the crude extract the enzyme activity could not be determined exactly.

the enzyme complex. Small amounts of purified enzyme complex in low yield could be obtained by running the chromatography columns at high speed with an FPLC pump system. The purification steps are summarized in Table 2. A Triton X-100 extraction was followed by application to a hydrophobic phenyl-Sepharose CL-4B column, where the enzyme remained tightly bound but was released at low ionic strength. Concentration and further purification was achieved by ultracentrifugation. After adsorption chromatography on hydroxyapatite a pure enzyme preparation was obtained.

In SDS-PAGE, the purified enzyme complex from $T$. aquaticus gave four bands (Fig. 1, lane 3), similar to those of the enzyme complex from Bacillus subtilis (lane 4). In contrast, the bovine heart complex (lane 2) showed five bands with different migration behaviour. The order of the components is the same for both the mammalian and the bacterial pyruvate dehydrogenase complexes (Barrera et al., 1972; Visser et al., 1980), with the exception of component $X$, which appeared just below the E3 component in the case of the bovine enzyme complex (DeMarcucci \& Lindsay, 1985). For T. aquaticus the identity of the upper band with the E2 component was established by the reaction of its biotinylated lipoyl residues with streptavidin, while the second electrophoretic band comigrated with a preparation of the purified free E3 component (not shown).

For the different subunits of the pyruvate dehydrogenase complex from $T$. aquaticus the following $M_{\mathrm{r}}$ values were determined from the migration distances in SDSPAGE in relation to reference proteins: $E 1 \alpha, 39600$; $\mathrm{E} 1 \beta, 37500$; E2, 58500 ; E3, 53900.

The $M_{\mathrm{r}}$ of the native pyruvate dehydrogenase complex from $T$. aquaticus was determined by ultracentrifugation for $3 \mathrm{~h}$ in a linear 10 to $50 \%$ sucrose gradient at $145000 \mathrm{~g}$ with the enzyme complexes from $E$. coli and bovine heart as references. The $T$. aquaticus enzyme complex sedimented faster than the enzyme complexes from both the other organisms, and an $M_{\mathrm{r}}$ value of $11.3 \times 10^{6}$ was calculated (Martin \& Ames, 1961). Similar results were obtained by gel-filtration on a FPLC Superose 6 column, where the $T$. aquaticus enzyme complex migrated faster than both the bovine and the $E$. coli complexes and an $M_{\mathrm{r}}$ value of $9.1 \times 10^{6}$ was determined.

The pyruvate dehydrogenase complex from $T$. aquaticus was negatively stained with uranyl oxalate (Fig. 2) under conditions that favoured disaggregation. Only the relatively stable E2 core remained intact, and showed a regular hexameric ring structure.

\section{Immunological cross-reactivity}

The electrophoretic pattern of the pyruvate dehydrogenase complex from $T$. aquaticus resembled that of type II, as found in Gram-positive bacteria and eukaryotic organisms. This was confirmed by immunotitration with polyclonal rabbit antibodies against the purified $T$. aquaticus enzyme complex. These antibodies were able to inactivate not only the pyruvate dehydrogenase complex from $T$. aquaticus but equally that from $B$. subtilis and, with rather less efficiency, that from bovine heart. No cross-reactivity, however, was observed with the pyruvate dehydrogenase complex from E. coli (Fig. 3).

\section{Kinetic characterization of the T. aquaticus enzyme complex}

The catalytic activity of the pyruvate dehydrogenase complex from $T$. aquaticus increased with the 


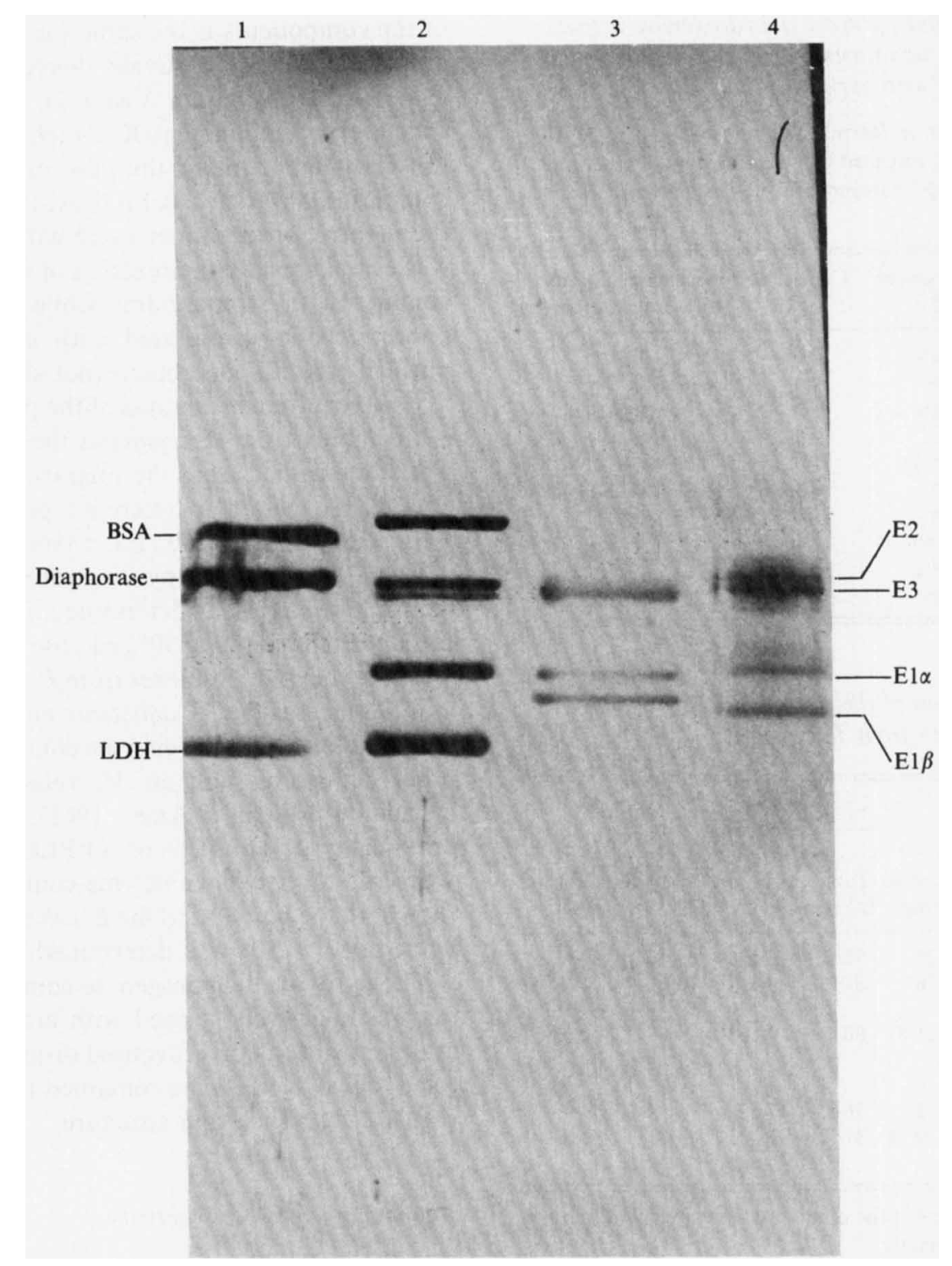

Fig. 1. SDS-PAGE of purified pyruvate dehydrogenase complexes from $T$. aquaticus (lane 3), beef heart (lane 2) and $B$. subtilis (lane 4). The order of components of the B. subtilis enzyme complex is indicated on the right. Lane 1 shows the reference proteins: bovine serum albumin (BSA), diaphorase from pig heart, and lactate dehydrogenase (LDH) from pig muscle. A total of $1.5 \mu \mathrm{g}$ of each protein was applied onto the gel.

temperature up to a maximum at $72{ }^{\circ} \mathrm{C}$. This increase gave no simple linear pattern in the Arrhenius plot; rather it appeared to consist of two linear parts corresponding to activation energies of about $80 \mathrm{~kJ} \mathrm{~mol}^{-1}$ in the lower $\left(<40^{\circ} \mathrm{C}\right)$ and $58 \mathrm{~kJ} \mathrm{~mol}^{-1}$ in the upper $\left(>50^{\circ} \mathrm{C}\right)$ temperature range (Fig. $4 a$ ). Beyond the temperature maximum the activity of the enzyme complex steeply declined and it became completely inactivated above $90^{\circ} \mathrm{C}$. With respect to $\mathrm{pH}$ values the overall activity of the pyruvate dehydrogenase complex showed a broad optimum between pH 5 and 8 with a maximum at $\mathrm{pH} 7 \cdot 2$ (Fig. $4 b$ ).

Besides pyruvate the pyruvate dehydrogenase complex from $T$. aquaticus accepted only 2-oxobutyrate as a substrate. The Michaelis constant for 2-oxobutyrate is tenfold higher and the maximum velocity of its conversion one-third of those for pyruvate (Table 3). Substrate inhibition was observed for both compounds at concentrations tenfold higher than the $K_{\mathrm{m}}$ value. Table 3 also shows the Michaelis constants for NAD and 


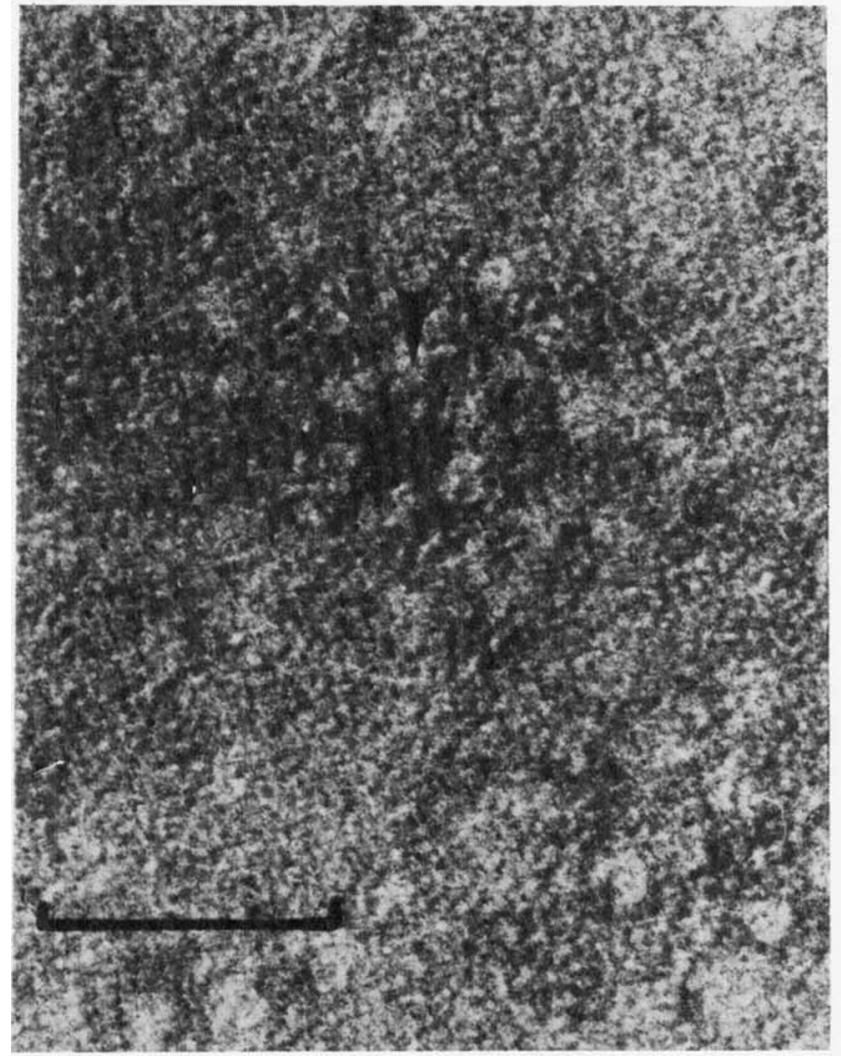

Fig. 2. Electron micrograph of the purified pyruvate dehydrogenase complex from $T$. aquaticus, negatively stained with uranyl oxalate. The bar corresponds to $20 \mathrm{~nm}$. The arrow shows an intact E2 core.

coenzyme A. In all cases, simple Michaelis-Menten behaviour was observed. As with the pyruvate dehydrogenase complex from other sources and other thiamindiphosphate-dependent enzymes complete removal of this cofactor caused irreversible loss of enzyme activity. About $18 \%$ of the cofactor remained tightly bound to the enzyme complex even after extensive dialysis. The $K_{\mathrm{m}}$ value for thiamin diphosphate in Table 3 was, therefore, corrected for this residual amount of bound cofactor.

2-Oxoacids other than pyruvate and 2-oxobutyrate were competitive inhibitors of the $T$. aquaticus pyruvate dehydrogenase complex with respect to pyruvate. The inhibition decreased with increasing chain length (Table 3). With long-chain 2-oxoacids, e.g. 2-oxocaprylate, however, the enzyme complex showed a remarkably strong non-competitive inhibition, which exceeded the competitive inhibition (not shown).

\section{Regulation of the pyruvate dehydrogenase complex from T. aquaticus}

Mammalian pyruvate dehydrogenase is regulated by reversible phosphorylation (Reed, 1981). Pre-incubation

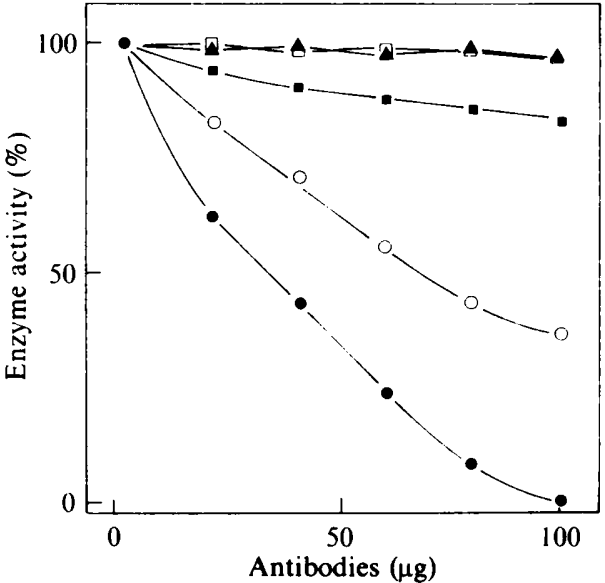

Fig. 3. Immunotitration of purified pyruvate dehydrogenase complexes from $T$. aquaticus $(O), B$. subtilis $(O), E$. coli $(\square)$ and bovine heart $(\square)$ with polyclonal rabbit antibodies against the purified pyruvate dehydrogenase complex from $T$. aquaticus, and of pyruvate dehydrogenase complex from $T$. aquaticus with rabbit control serum ( $\Delta)$. The enzyme preparations $(50 \mu \mathrm{g}$ each) were incubated together with the antibodies in a total volume of $0.5 \mathrm{ml} 0.1 \mathrm{M}$-potassium phosphate, pH $7 \cdot 6$, at $20^{\circ} \mathrm{C}$ for $30 \mathrm{~min}$, and for further $90 \mathrm{~min}$ at $4{ }^{\circ} \mathrm{C}$. The overall activity of the pyruvate dehydrogenase complex was determined in the supernatant after centrifugation of the samples at 12000 r.p.m. for $5 \mathrm{~min} .100 \%$ corresponds to an enzyme activity of $5.5 \mathrm{nkat} \mathrm{ml}^{-1}$.

Table 3. Kinetic constants of the pyruvate dehydrogenase complex from $T$. aquaticus

\begin{tabular}{lccc}
\hline \hline \multicolumn{1}{c}{ Compound } & $\begin{array}{c}K_{\mathrm{m}} \\
(\mathrm{M})\end{array}$ & $\begin{array}{c}V \\
\left(\mathrm{nmol} \mathrm{s}^{-1}\right)\end{array}$ & $K_{\mathrm{i}}$ \\
\hline Pyruvate & $3.9 \times 10^{-4}$ & $8 \cdot 2$ & - \\
2-Oxoglutarate & $4.1 \times 10^{-3}$ & 2.5 & - \\
Thiamin diphosphate & $0.2 \times 10^{-6}$ & ND & - \\
Coenzyme A & $9.2 \times 10^{-6}$ & ND & - \\
NAD & $7.3 \times 10^{-5}$ & ND & - \\
Glyoxylate & - & & $6.5 \times 10^{-4}$ \\
2-Oxo-n-valerate & - & & $6 \times 10^{-3}$ \\
2-Oxo-n-caproate & - & & $34 \times 10^{-3}$ \\
\hline \hline
\end{tabular}

ND, Not determined.

of crude extract from $T$. aquaticus ( $30 \mathrm{mg}$ protein $\mathrm{ml}^{-1}$ ) with $1 \mathrm{mM}-\mathrm{ATP}$ in the presence of $1.2 \mathrm{mM}-\mathrm{MgCl}_{2}$, $0.1 \mathrm{~mm}$-EDTA, $0.1 \mathrm{~mm}$-EGTA, $2 \mathrm{~mm}$-DTT in $50 \mathrm{~mm}$ $\mathrm{MOPS} / \mathrm{HCl}$, pH 7.0, at $70^{\circ} \mathrm{C}$, however, caused no change in the pyruvate dehydrogenase activity. When the enzyme complex was pre-incubated with GTP instead of ATP time-dependent inhibition was observed, which reached a plateau at $51 \%(0.5 \mathrm{~mm}-\mathrm{GTP})$ and $67 \%$ (1 mM-GTP) inhibition after $10 \mathrm{~min}$. This inhibition could be partially reversed by gel-filtration on a Superose 6 column (Table 4), which makes covalent modification unlikely, though reactivation of the enzyme complex by a complex-bound phosphatase during gel-filtration could 


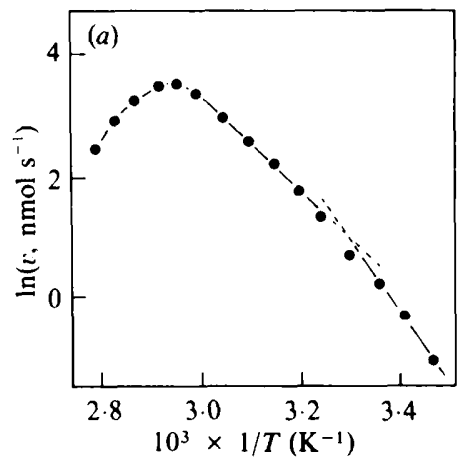

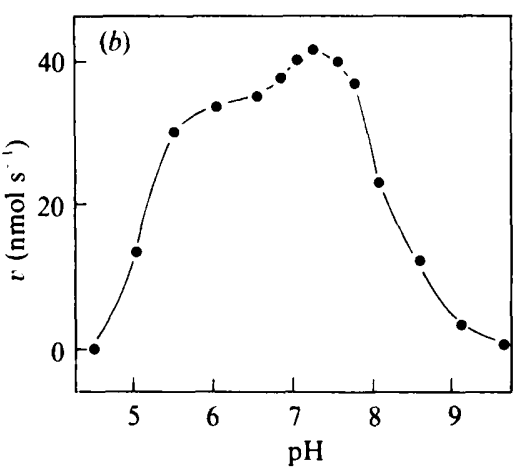

Fig. 4. Effect of temperature (a) and $\mathrm{pH}(b)$ on the enzymic activity of the pyruvate dehydrogenase complex from $T$. aquaticus. The overall activity of the enzyme complex was tested with $30 \mu \mathrm{g}$ enzyme per $\mathrm{ml}$ of test mixture, $2.0 \mathrm{mM}$-pyruvate in $0.1 \mathrm{M}$-potassium phosphate, $\mathrm{pH} 7.6$. For the $\mathrm{pH}$ curve the buffer system of Teorell \& Stenhagen (1938) was applied instead of potassium phosphate; the temperature was $70^{\circ} \mathrm{C}$.
Table 4. Gel-filtration of GTP-inactivated pyruvate dehydrogenase complex from $T$. aquaticus

Samples of crude extract of $T$. aquaticus $(3 \mathrm{mg}$ protein) were incubated with different amounts of GTP in $50 \mathrm{mM}-\mathrm{MOPS} / \mathrm{HCl}$, pH 7.0, $1.2 \mathrm{~mm}-\mathrm{MgCl}_{2}, 0.1 \mathrm{~mm}$-EDTA, 0.12 mM-EGTA, $2 \mathrm{~mm}-$ DTT in a total volume of $0.5 \mathrm{ml}$ at $70^{\circ} \mathrm{C}$ for $25 \mathrm{~min}$. Then the samples were applied to a Superose 6 column equilibrated with MOPS/ $\mathrm{HCl}, \mathrm{pH} \mathrm{7.0,} \mathrm{and} \mathrm{connected} \mathrm{with} \mathrm{an} \mathrm{FPLC} \mathrm{system.} \mathrm{The}$ active fractions were pooled and tested after elution.

\begin{tabular}{cccccc}
\hline & \multicolumn{2}{c}{ Pyruvate dehydrogenase activity } \\
\cline { 2 - 3 } $\begin{array}{c}\text { GTP concentration } \\
\text { in incubation assay } \\
(\mathrm{mM})\end{array}$ & $\begin{array}{c}\text { After } \\
\text { pre-incubation }\end{array}$ & & \multicolumn{2}{c}{$\begin{array}{c}\text { After } \\
\text { gel-filtration }\end{array}$} \\
\cline { 2 - 3 } \cline { 5 - 6 } & $\mathrm{nmol} \mathrm{s}{ }^{-1}$ & $\%$ & & $\mathrm{nmol} \mathrm{s}^{-1}$ & $\%$ \\
\hline 0 & 5.8 & 100 & & 4.2 & 100 \\
0.5 & 3.1 & 53 & & 3.7 & 88 \\
1.0 & 2.2 & 38 & & 3.6 & 86 \\
\hline \hline
\end{tabular}

not be completely ruled out. To test this $T$. aquaticus was grown for $8 \mathrm{~h}$ on medium M162 in the presence of ${ }^{32} \mathrm{P}_{\mathrm{i}}$. The crude extract after Triton X-100 extraction was applied to SDS-PAGE and an autoradiographic film was exposed to the gel. After exposure for $15 \mathrm{~d}$ bands appeared on the film in the upper $M_{\mathrm{r}}$ range above 68000 . However, no darkening could be detected in the $M_{\mathrm{r}}$ range between 36000 and 60000 , indicating that there was no phosphorylation of the subunits of the pyruvate dehydrogenase complex.

\section{Discussion}

The subunit structure of the El component, the high apparent $M_{\mathrm{r}}$ of the native enzyme complex, and the symmetry of the E2 core as derived from electron micrographs [quite similar to the E2 component from $B$. stearothermophilus, yeast or mammals (Henderson et al., 1979; Junger et al., 1973; Bleile et al., 1981)] clearly showed that the pyruvate dehydrogenase complex of $T$. aquaticus belongs to type II. If it can be taken as a general rule that type I complexes are limited to Gram-negative bacteria, while Gram-positive bacteria and eukaryotes. possess type II complexes, our finding supports the classification of $T$. aquaticus as a Gram-positive bacterium (Hensel et al., 1986), in contrast to its previous description as a Gram-negative bacterium (Brock \& Freeze, 1969). Though structural features of enzymes are only a crude tool for phylogenetic classification of organisms, they have been successfully applied in other cases, e.g. with citrate synthase and succinate thiokinase, where distinct structural forms can be related to Gramnegative bacteria on the one hand and Gram-positive bacteria and eukaryotes on the other hand (Weitzman \& Jaskowska-Hodges, 1982).

The close relationship between the type II complexes is confirmed by the cross-reactivity of the pyruvate dehydrogenase complexes from $T$. aquaticus and $B$. subtilis and the lack of any immunological reaction with the type I enzyme complex from $E$. coli. The clear crossreactivity between the bovine and the $T$. aquaticus enzyme complexes is striking. Comparison of pyruvate dehydrogenase complexes from different organisms, however, has revealed large species-specific differences among the E1 and the E2 components, while the E3 component is highly conserved (Guest, 1978), and may be responsible for the immunological cross-reactivity between far-distant species like Thermus and cattle.

The regulation of biosynthesis of the pyruvate dehydrogenase complex in T. aquaticus seems to be similar to that reported for E. coli (Dietrich \& Henning, 1970). High enzyme activities were found with pyruvate, an internal inducer of the ace operon in $E$. coli, activities were low with acetate and other carbon sources such as glutamate, succinate and glycerol, while growth on glucose yielded intermediate values. Thus, the pyruvate dehydrogenase complex from $T$. aquaticus, like that from E. coli (Engel-Rae \& Henning, 1973) seems not to be sensitive to catabolite repression. Accumulation of 
pyruvate rather than direct induction may be responsible for the effect of glucose. In the complete medium the induction of enzyme activity by pyruvate is less pronounced because of the presence of different metabolites which may influence the regulation of biosynthesis of the enzyme complex.

The relative instability of the $T$. aquaticus pyruvate dehydrogenase complex compared with those from mesophilic bacteria and eukaryotes is remarkable. Proteolytic degradation cannot be ruled out, though EDTA and PMSF as protease inhibitors were present during the purification procedure. Pyruvate dehydrogenase complexes from other sources were subject to proteolytic attack, especially on the E2 component. The characterized degradation products partly retained their enzymatic activity (Gebhardt et al., 1978; Kresze \& Ronft, 1980), but no such degradation products of the $T$. aquaticus enzyme complex were found. Dissociation of the enzyme complex into its components may also cause inactivation. Dissociation of subunits of the E3 component occurs during chromatographic steps and ultracentrifugation (Lehmacher \& Bisswanger, 1988). Addition of the E3 component to preparations of the enzyme complex, however, caused only a slight recovery of the overall activity.

The instability of the $T$. aquaticus pyruvate dehydrogenase complex is also reflected by its poor temperature stability. While $T$. aquaticus itself is able to grow at temperatures higher than $80^{\circ} \mathrm{C}$, its pyruvate dehydrogenase complex becomes considerably inactivated above $70{ }^{\circ} \mathrm{C}$. Since three enzyme components are involved in the overall reaction, the thermal behaviour of the complex is dictated by the most labile one. Both the E1 and the E2 components are somewhat labile, whereas the E3 component proved to be relatively stable (Lehmacher \& Bisswanger, 1988).

A biphasic behaviour pattern with a transition at about $45^{\circ} \mathrm{C}$ is observed with various thermophilic enzymes, including the E3 component isolated from $T$. aquaticus (Lehmacher \& Bisswanger, 1988). Thermophilic enzymes must maintain their native structure over a very broad temperature range, and the transition temperature between the two phases coincides with the temperature maximum of many mesophilic enzymes. The biphasic behaviour may be an adaption of the enzyme to extreme temperature conditions, with a transition to a metastable conformation in the upper temperature range (Nickerson, 1973; Privalov, 1979; Jaenicke, 1981). For the pyruvate dehydrogenase complex it must be borne in mind that the temperature profile of the overall reaction contains contributions of the different enzyme components and cannot, therefore, be treated in a simple way.

The regulation of the pyruvate dehydrogenase com- plex of Gram-positive bacteria is not yet well understood. As it is a key enzyme, connecting the glycolytic chain with the citric acid cycle its activity should be subject to strict control. The pyruvate dehydrogenase complex from Gram-negative bacteria like $E$. coli and Salmonella typhimurium is controlled allosterically (Bisswanger, 1984), and the enzyme complexes from higher organisms are regulated by reversible phosphorylation of their E1 component (Reed, 1981). Neither of these regulatory mechanisms could be detected in Grampositive bacteria. This was also the case with the pyruvate dehydrogenase complex from $T$. aquaticus. The only regulatory mechanism observed so far is an inhibition by GTP. This occurred, however, at relatively high concentrations.

The substrate specificity of the pyruvate dehydrogenase complex from $T$. aquaticus is similar to that of the mammalian and the $E$. coli complexes (Blass \& Lewis, 1973; Bisswanger, 1981; Pettit \& Reed, 1982). Pyruvate and 2-oxobutyrate are the only substrates accepted. Glyoxylate and higher 2-oxoacids act as competitive inhibitors, and their inhibitory effects decrease with increasing chain length. A strong non-competitive inhibition by long-chain 2-oxoacids is observed only with the enzyme complex from $T$. aquaticus. This may result from interactions of the non-polar hydrocarbon chains of the 2-oxoacids with the enzyme surface, which is more hydrophobic in thermophilic proteins than in mesophilic ones (Jaenicke, 1981; Zuber, 1981). Together with thiamin-diphosphate-dependent enzymes from other sources (Morey \& Juni, 1968; Bisswanger, 1974; Butler et al., 1977) the $T$. aquaticus pyruvate dehydrogenase complex shares the poorly understood feature, that this cofactor, though being non-covalently bound, cannot be completely removed from the enzyme without destroying its catalytic activity.

In its overall structural features, the pyruvate dehydrogenase complex from $T$. aquaticus shows no significant differences from those of mesophilic organisms that could be attributed to its thermophilic character. Further investigations are projected to explore the adaptation of this enzyme complex to high temperature conditions.

We are grateful to Mrs J. Jenkins for critical reading of the manuscript.

\section{References}

argos, P., Rossmann, M. G., Grau, U. M., Zuber, H., Frank, G. \& TRATSCHIN, J. D. (1979). Thermal stability and protein structure. Biochemistry 18, 5698-5703.

Barrera, C. R., Namihara, G., Hamilton, L., Munk, P., Eley, M. H., LINN, T. C. \& REED, L. J. (1972). $\alpha$-Keto acid dehydrogenase complexes. XVI. Studies on the pyruvate dehydrogenase complexes from bovine kidney and heart. Archives of Biochemistry and Biophysics 148, 343-358. 
Bisswanger, H. (1974). Regulatory properties of the pyruvate dehydrogenase complex from Escherichia coli. Thiamine pyrophosphate as an effector. European Journal of Biochemistry 48, 377-387.

BisSWANGER, H. (1981). Substrate specificity of the pyruvate dehydrogenase complex from Escherichia coli. Journal of Biological Chemistry 256, 815-822.

Bisswanger, H. (1984). Cooperativity in highly aggregated enzyme systems. A slow transition model for the pyruvate dehydrogenase complex from Escherichia coli. Journal of Biological Chemistry 259, $2457-2466$

BLASS, J. P. \& LEWIS, C. A. (1973). Kinetic properties of the partially purified pyruvate dehydrogenase complex of ox brain. Biochemical Journal 131, 31-37.

Bleile, D. M., Hackert, M. L., Pettit, F. H. \& Reed, L. J. (1981), Subunit structure of dihydrolipoyl transacetylase component of pyruvate dehydrogenase complex from bovine heart. Journal of Biological Chemistry 256, 514-519.

Brock, T. D. \& FreEZE, H. (1969). Thermus aquaticus gen.n. and sp.n., a nonsporulating extreme thermophile. Journal of Bacteriology 98 , 289-297.

Butler, J. R., Pettit, F. H., Davis, P. F. \& Reed, L. J. (1977). Binding of thiamin thiazolone pyrophosphate to mammalian pyruvate dehydrogenase and its effects on kinase and phosphatase activities. Biochemical and Biophysical Research Communications 74, 1667-1674.

Degryse, E., Glansdorff, N. \& Piérard, A. (1978). A comparative analysis of extreme thermophilic bacteria belonging to the genus Thermus. Archives of Microbiology 117, 189-196.

DeMarcucci, O. \& Lindsay, J. G. (1985). Component X, an immunologically distinct polypeptide chain associated with mammalian pyruvate dehydrogenase multi-enzyme complex. European Journal of Biochemistry 147, 641-648.

Dietrich, J. \& HenNing, U. (1970). Regulation of the pyruvate dehydrogenase complex synthesis in Escherichia coli K12. Identifcation of the inducing metabolite. European Journal of Biochemistry 14, 258-269.

ENGel-RAe, M. \& Henning, U. (1973). Synthesis of the $E$. coli pyruvate dehydrogenase complex: non-dependence on $3^{\prime}-5^{\prime}$-cyclic AMP. Biochemical and Biophysical Research Communications 53, 812-817.

Fairbanks, G., Steck, T. L. \& Wallach, T. F. H. (1971). Electrophoretic analysis of the major polypeptides of the human erythrocyte membrane. Biochemistry 10, 2606-2627.

Gebhardt, C., Mecke, D. \& Bisswanger, H. (1978). Dihydrolipoamide transacetylase from Escherichia coli: evidence for internal gene duplication. Biochemical and Biophysical Research Communications 84, 508-514.

GUEST, J. R. (1978). Aspects of the molecular biology of lipoamide dehydrogenase. Advances in Neurology 21, 219-244.

HARTREE, E. F. (1972). Determination of protein: a modification of the Lowry method that gives linear photometric responses. Analytical Biochemistry 48, 422-427.

Henderson, C. E., Perham, R. N. \& Finch, J. T. (1979). Structure and symmetry of $B$. stearothermophilus pyruvate dehydrogenase complex and implications for eucaryote evolution. Cell 17, 85-93.

HeNSEL, R., Demharter, W., KANDLER, O., KROPPENSTEDT, R. M. \& STACKEBRANDT, E. (1986). Chemotaxonomic and molecular-genetic studies of the genus Thermus: evidence for a phylogenetic relationship of Thermus aquaticus and Thermus ruber to the genus Deinococcus. International Journal of Systematic Bacteriology 36, 444-453.

Heukeshoven, J. \& Dernick, R. (1985). Simplified method for silver staining of proteins in polyacrylamide geis and the mechanism of silver staining. Electrophoresis 6, 103-112.

JAENICKE, R. (1981). Enzymes under extremes of physical conditions. Annual Review of Biophysics and Bioengineering 10, 1-67.

Junger, E., Reinauer, H., Wais, U. \& UllRich, J. (1973). Electron microscopic study of pyruvate dehydrogenase from Saccharomyces carlsbergensis. Hoppe-Seyler's Zeitschrift für Physiologische Chemie 354, 1655-1658.
Kresze, G.-B. \& RonfT, H. (1980). Bovine kidney pyruvate dehydrogenase complex. Limited proteolysis and molecular structure of the lipoate acetyltransferase component. European Journal of Biochemistry 112, 589-599.

LAEMMLI, U. K. (1970). Cleavage of structural proteins during the assembly of the head of bacteriophage T4. Nature, London 227 , 680-685.

Lehmacher, A. \& Bisswanger, H. (1988). Adaption of enzymes to high temperature. Isolation and characterization of the lipoamide dehydrogenase from Thermus aquaticus. Biochemistry (Life Science Advances) 7, 29-33.

Martin, R. G. \& Ames, B. N. (1961). A method for determining the sedimentation behavior of enzymes: application to protein mixtures. Journal of Biological Chemistry 236, 1372-1379.

Mellema, J. E., van Bruggen, E. S. \& Gruber, M. (1967). Uranyl oxalate as a negative stain for electron microscopy of proteins. Biochimica et Biophysica Acta 140, 180-182.

MoREY, A. V. \& JUNI, E. (1968). Studies on the nature of the binding of thiamine pyrophosphate to enzymes. Journal of Biological Chemistry 243, 3009-3019.

NiCKERSON, K. W. (1973). Biological functions of multistable proteins. Journal of Theoretical Biology 40, 507-515.

OsHIMA, T. \& ImAHORI, K. (1974). Description of Thermus thermophilus comb.nov., a nonsporulating thermophilic bacterium from a Japanese thermal spa. International Journal of Systematic Bacteriology 24, 102-112.

Packman, L. C., Borges, A. \& Perham, R. N. (1988). Amino acid sequence analysis of the lipoyl and peripheral subunit-binding domains in the lipoate acetyltransferase component of the pyruvate dehydrogenase complex from Bacillus stearothermophilus. Biochemical Journal 252, 79-86.

Pettit, F. H. \& Reed, L. J. (1982). Pyruvate dehydrogenase complex from bovine kidney and heart. Methods in Enzymology 89, 376-386.

Privalov, P. L. (1979). Stability of proteins. Advances in Protein Chemistry 33, 167-241.

ReED, L. J. (1974). Multienzyme complexes. Accounts of Chemical Research 7, 40-46.

REED, L. J. (1981). Regulation of mammalian pyruvate dehydrogenase complex by a phosphorylation-dephosphorylation cycle. Current Topics in Cellular Regulation 18, 95-106.

SCHMincke-OTt, E. \& Bisswanger, H. (1981). Dihydrolipoamide dehydrogenase component of the pyruvate dehydrogenase complex of Escherichia coli K12. Comparative characterization of the free and the complex-bound component. European Journal of Biochemistry $114,413-420$

SCHWARTZ, E. R. \& REED, L. J. (1970). Regulation of the activity of the pyruvate dehydrogenase complex of Escherichia coli. Biochemistry 9 , 1434-1439.

TeORell, T. \& Stenhagen, E. (1938). Ein Universalpuffer für den pHBereich 2,0-12,0. Biochemische Zeitschrift 299, 416-419.

Visser, J., Kester, H. \& Huigen, A. (1980). Purification and some properties of the pyruvate dehydrogenase complex of Bacillus subtilis. FEMS Microbiology Letters 9, 227-232.

Weitzman, P. D. J. \& JASKowska-Hodges, H. (1982). Patterns of nucleotide utilisation in bacterial succinate thiokinase. FEBS Letters 143, 237-240.

WiELAND, O. H. (1983). The mammalian pyruvate dehydrogenase complex: structure and regulation. Reviews of Physiology and Biochemical Pharmacology 96, 123-169.

YeAman, S. J. (1989). The 2-oxo acid dehydrogenase complexes: recent advances. Biochemical Journal 257, 625-632.

Yoshida, T., LOREnCE, R. M., Choc, M.-G., TARR, G. E., Findling, K. L. \& FEE, J. A. (1984). Respiratory proteins from the extremely thermophilic aerobic bacterium Thermus thermophilus. Journal of Biological Chemistry 259, 112-123.

ZUBER, H. (1981). Structure and function of thermophilic enzymes. 32. Colloquium der Gesellschaft für Physiologische Chemie, pp. 114-127. Heidelberg: Springer-Verlag. 